\title{
EXPLORING THE QUALITY OF EMPLOYMENT IN ROMANIA AT DIFFERENT TERRITORIAL LEVELS
}

\author{
Irena MOCANU, Paul-Răzvan ŞERBAN \\ Institute of Geography, Romanian Academy
}

\begin{abstract}
The paper aims to explore the quality of employment at different territorial levels (national, macro-regional, regional, county and local level). The first section of the study approaches the quality of employment in terms of several perspectives (sociological, economic and geographical). Methodological aspects are discussed in the second section, with focus on the selection of statistical indicators by two main criteria: the relevance of the indicators and their availability for all the mentioned territorial levels. The largest part of the paper presents the analysis results, basically the typologies of the mentioned territorial levels in terms of selected indicators mirroring the quality of employment. The study shows that there exists a relationship between the situation of the quality of employment (weak, average or good) and the different territorial levels analysed.
\end{abstract}

Key Words: quality of employment, decent work, labour market, territorial level, Romania.

\section{Introduction}

The quality of employment is an issue of importance for everybody: people, institutions, governments, economic actors, communities. Thus, the quality of employment has increasingly become the focus of attention among labour market analysts, researchers from many and diverse fields of sciences, and policy makers in the European Union and worldwide.

The quality of employment is promoted by the European Union's official documents and strategies (e.g. Social Policy Agenda 2005, Europe 2020) as a "guiding principle" for rising standards and ensuring a more equitable sharing of progress. The three mutually reinforcing objectives - smart, sustainable, and inclusive growth - specified in the Europe 2020 Strategy (European Commission 2010) represent the background for the other European official documents and also for the theoretical, methodological or applied scientific papers which approach employment and social development (Balkyte and Tvaronavičiene 2010, Cooke and De Propris 2011, Lazaroiu and Roscia 2012, Budzianowski 2012, Leschke et al. 2012, Capros et al. 2014).

Geographically speaking, the labour market has an intrinsically local or spatially constituted level of operation and regulation (Peck 1996, Peck 2003, Martin 2000, Martin and Morisson 2003, Castree 2010, Weller and Campbell 2014).

The approach proposed in the present research is consistent with the international conceptual and methodological framework on the quality of employment. The aim of this paper is to analyse the quality of employment from a multi-territorial perspective, with a focus on two different and dependent research directions: firstly, to identify the statistical variables and indicators for analysing the quality of employment which are available at different territorial levels; secondly, to obtain territorial typologies in terms of quality of employment. The paper starts with a review of the literature which explores the very numerous statistical indicators of the quality of employment. This section contributes to highlighting the intrinsic territorial valence of the quality of employment. Also, in this part of the paper, the Multivariate Analysis is used to 
investigate macro-regional, regional, county and local typologies in terms of quality of employment.

\section{The quality of employment: different approaches}

In the economic and sociological literature, the term "quality of employment" is related with other terms, such as: decent work, quality of work, quality of working life, job quality or good / bad jobs (Bescond et al. 2003, Bonnet et al. 2003, Ghai 2003, Arvigan 2005, Johri 2005). The development of these concepts in terms of their definition has evolved from simple studies of job satisfaction towards more comprehensive evaluations of job and employment quality (Burchell et al. 2012).

The concept "decent work" launched by the International Labor Organization (ILO 1999) considers every aspect of employment, e.g. working conditions, rights, social dialogue, personal goals, as well as more standard measures such as income. "Decent work" implies opportunities to obtain decent and productive work, in such conditions of freedom, equity, security and human dignity (ILO 1999) but it is extremely vague and all-encompassing and almost impossible to measure across countries using the same set of statistical indicators (Burchell et al. 2012). The concept "decent work" is thus related to Sen's capability approach as it considers not only the availability of jobs, but a broad range of aspects associated with work which the individual has reason to value (Sen 1997, Clark 2000).

The concept "quality of work" is more comprehensive than "decent work" and it includes better jobs and a balance between working life and personal life; it implies better policies, fair remuneration, a work organisation adapted to the needs of both businesses and individuals; it is based on high skills, fair labour standards and decent levels of occupational health and safety and it includes the facilitation of occupational and geographical mobility (van Bastelaer 2002).

The "quality of employment" is a subjective and multidimensional concept, hence it is difficult to define. Reflecting this difficulty, it has no standard or agreed definition in the academic or expert literature. Being defined more broadly, it includes the objective characteristics related to employment (specific to the job and generally relating to the wider labour market), the characteristics of the worker, the match between the worker and the employment characteristics, and the worker's subjective evaluation (job satisfaction) of the employment characteristics. Very briefly, it implies the organisation of work and its adaptation in relation to the needs of both companies and employees (van Bastelaer 2002). Van Bastelaer and Hussmanns (2000) define quality of employment as a set of characteristics that determine the capability of employment to satisfy certain commonly accepted needs.

The concept of quality of employment implies a comprehensive and all-inclusive approach to the labour market that considers all aspects of work. The quality of employment is important not only due to reasons of individual welfare, but also because of its importance to the society as a whole (Sehnbruch 2004). The quality of employment matters as much as the quantity of employment, because employment is an important socio-economic dimension of life (a "space", using Sen's 1997 expression) in which inequality manifests itself not only through the unemployment rates but also through the job characteristics themselves.

High quality jobs are also generally the most productive ones, and they require higher levels of skills from workers. Low quality employment is not randomly distributed in the population. In general, women, youth, older people, less educated people, less skilled people, ethnic minorities and people who are disadvantaged in some way and/or are at the margins of the labour market are more likely to be in a low quality employment situation, perpetuating such disadvantages (van Bastelaer 2002). Conceptually, it may be useful to divide job quality into 
two broad areas, employment quality and work quality. Employment quality, referring to those aspects of the employment relationship that have a potential impact on the well-being of workers, covers all the aspects related to the employment contract (remuneration and working hours) and career development. Work quality, referring to how the activity of work itself and the conditions under which it takes place can affect the well-being of workers, is focused on the aspects linked with autonomy, intensity, social environment and physical environment (Muñoz de Bustillo et al. 2009).

In the scientific literature, there are many contributions in the field of quality of life highlighting the link between this one and the quality of employment (Harvey 2001, Greenhaus et al. 2003, Sehnbruch 2004, Gallie 2007), the level of education (Moretti 2004, Aceleanu 2012) and the life satisfaction (Andren and Martisson 2006, Ferrante 2009).

In Romania, the concern on the quality of employment is expressed at institutional and political levels and it is materialized by the strategies, national plans and programmes elaborated and implemented by the Ministry of Labour, Family, Social Protection and the Elderly, by the national, counties and locals agencies for employment, while being monitored/controlled by the Territorial Labour Inspectorate. All these official institutions and documents represent the legal background for numerous studies focused on the quality of employment in the larger framework of the quality of life (Zamfir 1990, Mărginean and Bălaşa 2005, Mărginean and Precupeţu 2008, Mărginean and Precupeţu 2011, Vasile et al. 2011).

Geography shares with the other disciplines the theoretical framework of the quality of employment concept, improving it, but there is no sub-disciplinary geographic direction on the "quality of employment". Rather, this topic is situated at the intersection of the subfields of economic, regional and social geographies (Weller and Campbell 2014). In completing the socio-economic approach, geographers offer a different perspective, being based namely on the spatial dimension. This approach implies several aspects, the most important ones being to point the following: the factors that distinguish geographically the characteristic features of employment and unemployment; the correlation of employment with territorial disparities (Goschin 2008), looking at the characteristic features and structure of employment and unemployment, including the evolution trends of the local and/or regional economy within a national context (Şerban and Tălângă 2015); the identification of socio-spatial effects of employment, qualification, requalification, professional updating and reconversion of labour at territorial level.

Labour geography, term coined by Herod (1997) to designate an emergent body of largely leftcritical research, has its roots in the sub-discipline of economic geography that focuses on employment issues. The labour geography approaches the employment issues emphasizing its acute awareness of power and inequality, and its left sensibility, politically speaking (Castree 2010).

In the mid- $20^{\text {th }}$ century, the geographer who upheld the idea that geography should study labour as a discipline was Renée Rochefort (1961), saying that if Geography wishes to remain a live science it ought to study labour, because labour is the most important human activity, it is the source of welfare, the force which permanently changes, organises and even destroys the surface of the Earth, the personality of an area resulting from the way society has exlpored and valorised its natural and labour resources just through labour (Rochefort 1961: 2).

Geographers view the quality of employment as an outcome of the multiple and inherently specialized structures and processes at work inside labour markets (Castree et al. 2004, Weller 2008), as a result of a complex and dynamic relation of labour. 


\section{Materials and methods}

Analysing the quality of employment follows some principles, including its applicability by national statistical institutions. This is one of the most important principles, vital for characterising the quality of employment at national level and for acting to improve it if at low levels. To capture the complete picture of the relations established between the different social and economical processes and phenomena that have shaped the quality of employment across the EU member-states and EU regions, the international system of statistical indicators should be supplemented, observing the rule of applicability/availability by all member-states, both at national and (macro)regional level and even at the local territorial one (Davoine et al. 2008). Furthermore, the international framework of statistical indicators should be adapted according to the existing data-base or to the specific country's socio-economic background (Ciutacu and Chivu 2007).

The main criteria for selecting the needed statistical indicators were their relevance to the Romanian labour market and their availability at all the different territorial levels considered in the analysis. The availability of the same statistical data at all four territorial levels is a very important aspect for mapping out the indicators and analysing them at different spatial levels. Some statistical indicators, which meet the two above-mentioned criteria, were identified in Sehnbruch's (2004) and Ciutacu and Chivu's approaches (2007). Sehnbruch (2004) analysed five dimensions of the Chilian labour-market, centred on income, social security coverage, contractual status, employment stability and professional training received. The Ciutacu and Chivu (2007) approach followed closely the Eurofound model of job and employment quality, their quality-of-employment analysis focusing on four aspects: career and employment security, development of skills, reconciliation of working and non-working life, health and well-being. These two studies have revealed that there are some indicators which might mirror the quality of employment at all territorial levels, meeting at the same time the desideratum of relevance for Romania and for the study-area, as well as the availability of data at all territorial levels. These indicators, employed in the present analysis, are: general rate of employment (EMPLOY); rate of unemployment (UR); rate of employment in agriculture (EMPLOYAGR); rate of employment in non-agricultural activities (divided into manufacturing sector EMPLOYMANUF and tertiary sector - EMPLOYTERT); and the percentage of employees per total employed population (EMPLOYEES). In our study, these indicators are computed from the statistical data available at macro-regional, regional, county and LAU2 levels provided by the National Institute of Statistics (TEMPO Online and the results of the Population and Housing Census 2011).

The method used to analyze these indicators is the Hierarchical Ascending Classification (Multivariate Analiysis). This method allowed us to obtain territorial typologies in terms of quality of employment, the Hierarchical Ascending Classification performing a precise hierarchy over large data sets which helps the rapid creation of nested partitions in a dataset (Bruynooghe 1977 quoted by Şerban and Tălângă 2015, Rokach and Maimon 2010).

The general rate of employment provides information on the extent to which an economy generates jobs, the empirical evidence suggesting that it has a higher correlation with economic development, measured by GDP per capita, than with the labour force participation rate (Akyeampong 1996, Anker et al. 2003). The lack of employment opportunities in the manufacturing sector and the insufficient level of development in the tertiary sector (whose restructuring is reflected by the depleted rate of employment values in the manufacturing and in the tertiary sectors) augmented the importance of agricultural activities (Ciutacu and Chivu 2007). In this way, the rate of employment in agriculture indicates that the increase of the population employed in this sector was due not so much to the needs of agriculture, as to the redundant workforce from other sectors of the urban economies (Mateoc-Sîrb et al. 2014). The economic structure of employment is linked with urbanization and the rapid rural-urban 
migration (in the case of developing countries, Anker et al. 2003) and with the inverse process of migration, from urban-to-rural, in the transition economies (lanoş 1999). Unemployment (loss of the labour-force potential) is the effect of the mismatch between the quality and quantity of labour offer and demand, reflected by the capacity of the local/regional/national economy to create new jobs and to maintain the existing ones (Mocanu 2010).

\section{Results and discussion}

National level. Once Romania joined the EU (in 2007) and once the financial and economic crisis set on (in 2008), the national labour market continued to be characterised by persistently low employment and high inactivity rates coupled with a shrinking working-age population due to population ageing and outward migration, as well as under-employment in agriculture (European Commission 2015).

The resulting taxonomy of the European employment quality models is based on an enlarged dataset that includes the Laeken indicators and it appears to identify four job quality systems in the EU. Romania is included in a new Member State cluster (together with Poland, Hungary, Bulgaria, Slovakia, the Czech Republic, Latvia, Lithuania and Estonia). This implies low productivity levels, low socio-economic security and unfavourable working conditions (e.g. high health risks), which are partly offset by the relatively low work intensity (Davoine et al. 2008).

The European Foundation for the Improvement of Living and Working Conditions (Eurofound 2013), which elaborated an inventory of employment and working conditions in Romania (starting with 2001), highlighted the main features of the national labour-market: a decreasing employment rate (which means, on the one hand, reduced employment security, and a fundamental goal of workforce employment policies, on the other hand); the existence of two labor-markets, one specific to urban economic activities and regulations, converging with the EU characteristics, and the other one, a "natural labour-market", characteristic of the rural space (where payment and taxation of the value of work are not made on a regular basis), with predominant agricultural activities and with a market economic mechanism which in many cases is not the rule; dependency of the quality of work and life on job satisfaction and revenue (Ciutacu and Chivu 2007).

Macro-regional level. Class 1 comprises two macro-regions (I and IV) in which the general quality of employment situation is close to the national average. An exception is made by the general occupancy, the employment in the manufacturing sector (above the national average, with a positive impact on the quality of employment) and the occupancy in tertiary activities (below the baseline, negatively affecting the quality of employment). Class 2 is represented by the Macro-region III which includes Bucharest-Ilfov region and the industrialized area of Prahova, Argeş and Dâmboviţa counties. In this context, the quality of employment is good, it being the cumulative effect of the indicator values analyzed: the general employment rate, the percentage of employees per total employed population and the rate of occupancy in tertiary activities have high values, above the baseline; the values of the unemployment rate and occupancy in agriculture are below the national average. Class 3 contains the Macro-region II, with a problematic quality of employment: the values of unemployment rate and of employment rate in agriculture (with negative impact on the quality of employment) are above the national average; concomitantly, the indicators with a positive effect on the quality of employment have values below the national average (Fig. 1). 


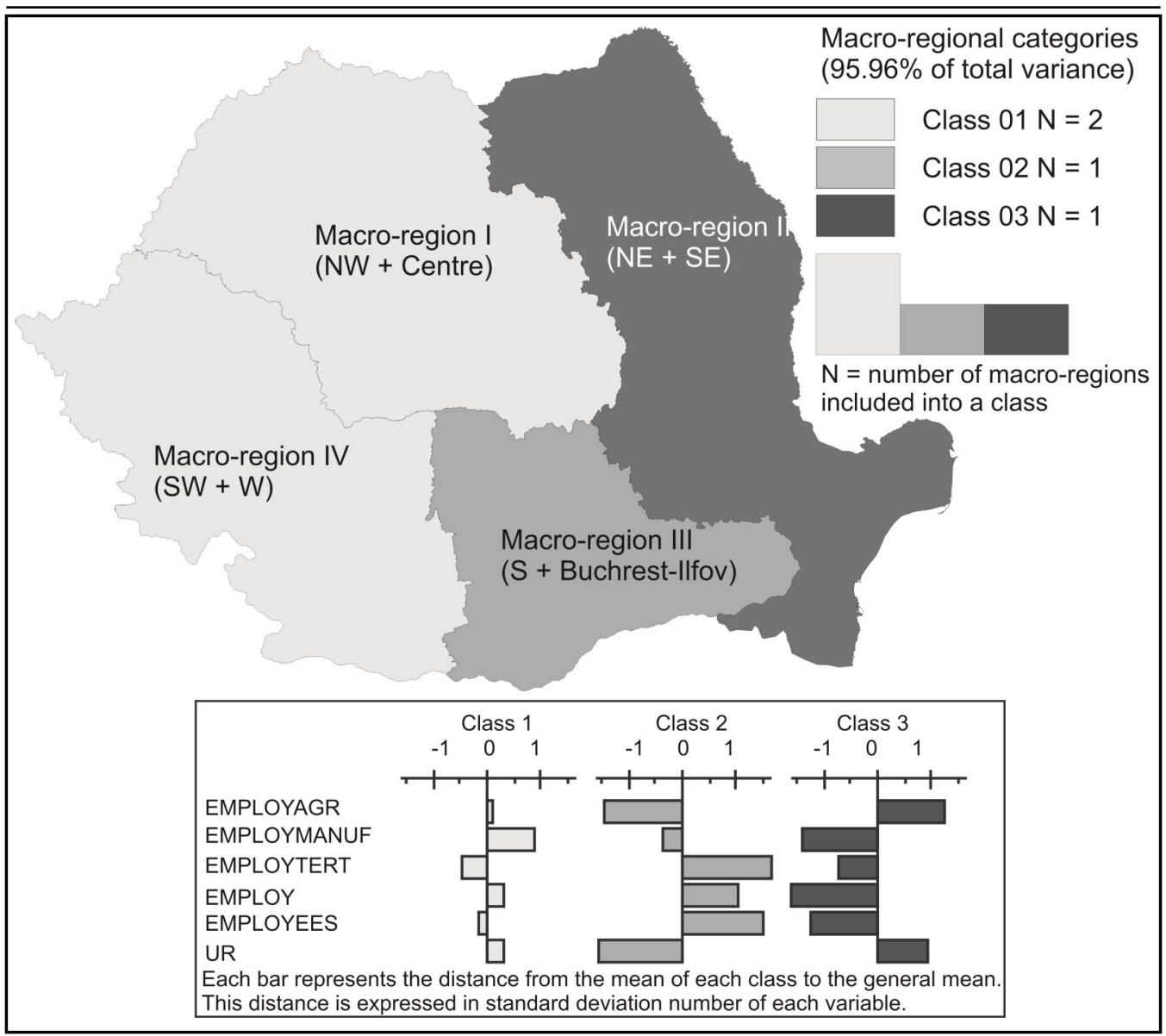

Fig. 1 - Types of macro-regions

Source: Population and Housing Census 2011, TEMPO Online, National Institute of Statistics Made with Philcarto (http://philcarto.free.fr)

Class $1=$ the general quality of employment situation is close to the national average, excepting two indicators (employment in the manufacturing sector - above the baseline and occupancy in tertiary activities - below the baseline);

Class 2 = the quality of employment is good due to the cumulative effect of the selected indicator (high values of the four indicators with a positive impact on the quality of employment and low values of the other two indicators - the occupancy in agriculture and the unemployment rate);

Class $3=$ a problematic quality of employment (the indicators with positive effect on the quality of employment have values below the national average).

The eight development regions are divided in the three classes. Class 1 includes the NorthEast, North-West, West and South-West regions. In this class, the quality of employment is notably distanced by the national average, because of the values of general occupancy below the national average, including the manufactured and tertiary sectors. Also, the problematic situation in terms of quality of employment is generated by the values of unemployment rate and of occupancy in agriculture, which are above the national average. Class 2 is represented 
only by the Centre region, which registered a high quality of employment. This is due to the benefit resulting from the values of general occupancy, the share of employees per total employed population and the employment in the tertiary sector, which are above the national average; at the same time, the indicators with a negative impact on the quality of employment (occupancy in agriculture and unemployment rate) registered values below the national average. Class 3 includes South, Bucharest-Ilfov and South-East regions in which the quality of employment is very close to the national average (excepting the share of employees per total employed population above the national average) (Fig. 2).

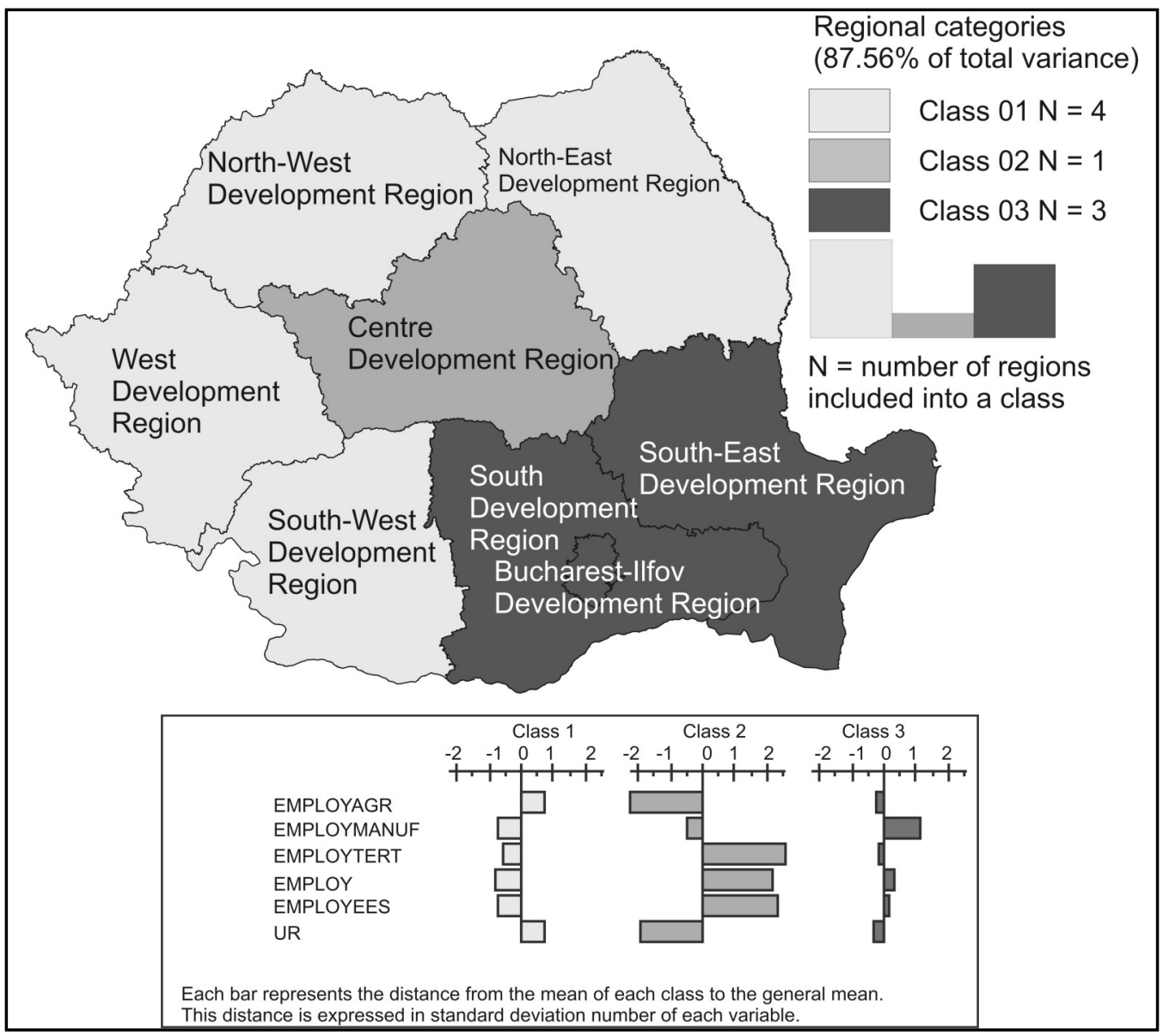

Fig. 2 - Types of regions

Source: Population and Housing Census 2011, TEMPO Online, National Institute of Statistics Made with Philcarto (http://philcarto.free.fr)

Class $1=$ the quality of employment is weak, notable distanced by the national average, the indicators with negative effect on the quality of employment being above the national average;

Class 2 = good quality of employment (the indicators with positive effect on the quality of employment are above the national average and those ones with a negative impact are below the baseline);

Class $3=$ the quality of employment is very close to the national average (excepting the share of employees per total employed population above the national average). 
County level. Class 1 has the largest number of counties in which the quality of employment is close to the national average: employment in manufacturing activities registered a positive deviation, which has a good impact on the quality of employment. Class 2 includes the western and central counties, but also two southern and south-eastern counties (Ilfov, Constanța) and the Bucharest Municipality. In the counties from the class 2, the quality of employment is good due to the above the national average values of the indicators with positive effect; also, the values of the unemployment rate and occupancy in agriculture (with a negative impact on the quality of employment) are below the national average. Class 3

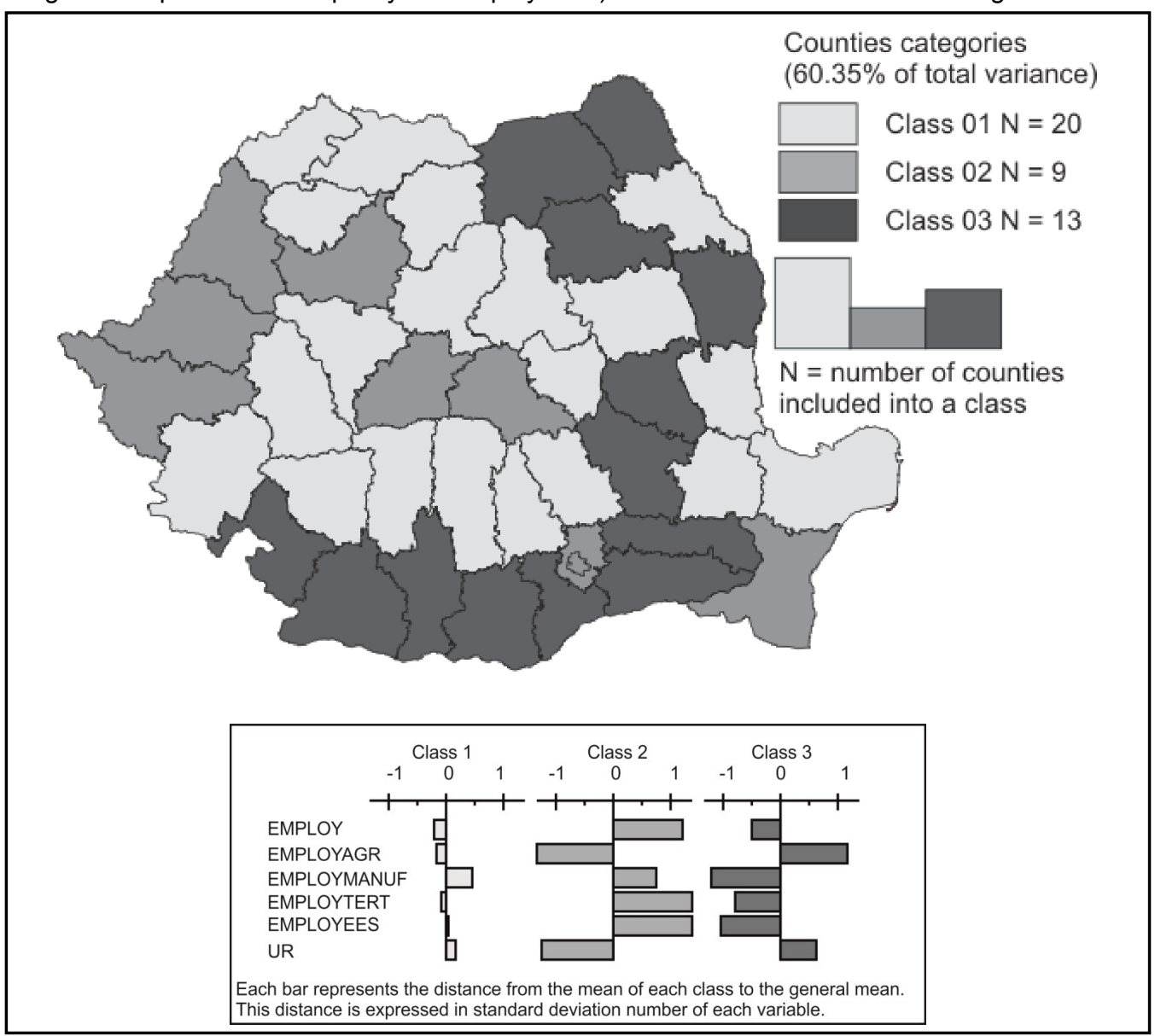

Fig.3 - Types of counties

Source: Population and Housing Census 2011, TEMPO Online, National Institute of Statistics Made with Philcarto (http://philcarto.free.fr)

Class $1=$ the quality of employment is close to the national average:

Class 2 = the quality of employment is good due to the above the national average values of the indicators with a positive effect; also, the values of the unemployment rate and the occupancy in agriculture (with a negative impact on the quality of employment) are below the national average;

Class $3=a$ weak quality of employment because of the sharp negative deviation in the case of all indicators with a positive effect. 
comprises the southern and eastern counties of Romania. These counties are characterized by a weak quality of employment because of the sharp negative deviation in the case of all indicators with a positive effect; concomitantly, the indicators with a negative impact on the quality of employment have values above the national average (Fig. 3).

In this study, the selected local level is represented by the 266 local administrative units of the Romanian Danube Valley (Fig. 4).

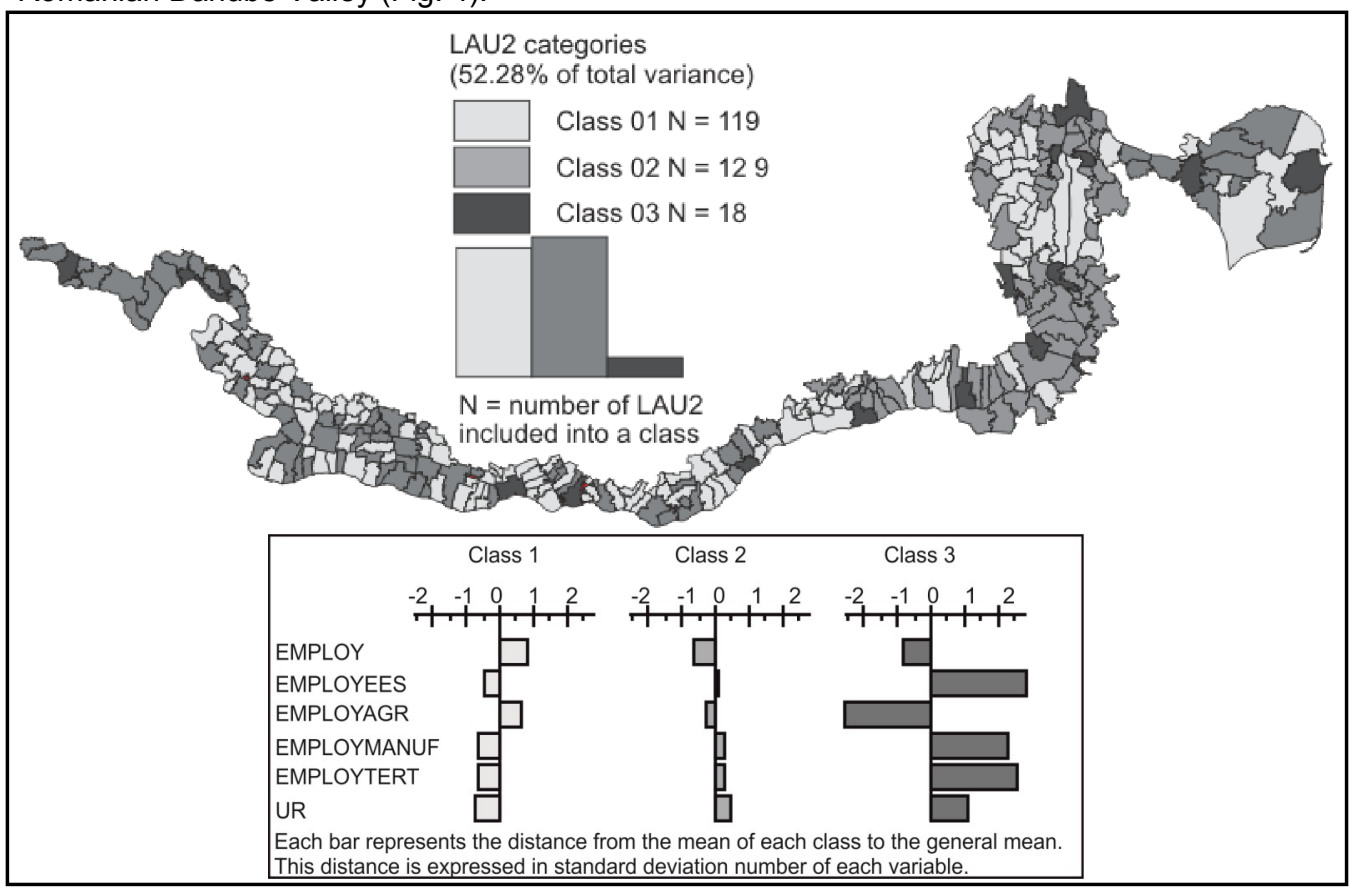

Fig. 4 - Types of LAU2

Source: Population and Housing Census 2011, TEMPO Online, National Institute of Statistics Made with Philcarto (http://philcarto.free.fr)

Class $1=$ the quality of employment is weak because of the sharp positive deviations registered by the occupancy in agriculture and because of the sharp negative deviations recorded by the indicators negatively impacting the level of the quality of employment;

Class $2=$ the quality of employment is relatively close to the national average, with some trends toward increasing the quality of employment (a weak positive deviation recorded by the occupancy in nonagricultural activities), but there still exist the positive sharp deviations of the rate of unemployment, the negative notable deviation of the general occupancy both with negative effects on the quality of employment;

Class $3=$ the quality of employment is relatively good due to the advantageous position against the national average value of indicators with a positive effect; concomitantly, the values of the unemployment rate is generally high and the general occupancy rate is lower than the baseline.

Four out of the 12 Danubian counties fall into two different classes: Galaţi, Brăila and Tulcea counties in the class with a quality of the employment close to the national average and Constanța in class 2 with a good quality of employment (Fig. 3). The closest to the national average are the indicators falling into classes 1 and 2, which include the largest extent of the Danubian territorial administrative units (all rural localities and the small Danubian towns). The quality of employment is conditional on the rural local economy, which shaped the local labour 
market and the general living conditions in the rural areas. Since agriculture represents the main rural economic activity in the Danube Valley, the quality of employment is low because of the high occupancy in agriculture (a sharp positive deviation impacted negatively the quality of employment level); also, occupancy values below the national average in non-agricultural activities have a negative effect on the quality of employment. The modeling role of agriculture is shown by the sharp negative deviation of the unemployment rate (class 1) and by the positive deviation in class 2 (where occupancy in agriculture is below the baseline). Class 3 included the majority of the Danubian urban territorial units that recorded a relatively good quality of the employment, compared with the rural area and the small Danubian towns (Fig. 4). The occupancy in non-agricultural activities is higher than the national average but the general occupancy represents a real problem because of the cumulated effects of restructuring the town industries (top specialisation in metallurgy in Galaţi, Călăraşi, Zimnicea and Tulcea cities and in the chemical industry in Turnu Măgurele - lanoş 1999). The effects of restructuring the town industry was primarily in the downscaling of specific activities and even in stopping them altogether, reducing jobs and closing down industrial units, hence growing unemployment. Along the Romanian Danube Valley, urban economies were severely affected by the restructuring process, the rural economy being dominated by subsistence.

\section{CONCLUSIONS}

Exploring the quality of employment in Romania at different territorial levels highlighted three main conclusions.

The majority of statistical units or territorial administrative units are included in classes with a weak quality of employment or close to the national average. This situation is obvious for class 1 (which comprises almost half of all macro-regions, regions, counties and the Danubian territorial administrative units) and class 3 (which includes about a third of all counties and regions) (Table 1).

Synthetic outline of different territorial levels in terms of quality of employment

Table 1

\begin{tabular}{|c|c|c|c|c|c|c|}
\hline Territorial & Class 1 & & Class 2 & & Class 3 & \\
\hline & $\begin{array}{l}\text { Negative } \\
\text { distance }\end{array}$ & $\begin{array}{l}\text { Positive dis- } \\
\text { tance }\end{array}$ & $\begin{array}{l}\text { Negative } \\
\text { distance }\end{array}$ & $\begin{array}{l}\text { Positive } \\
\text { distance }\end{array}$ & $\begin{array}{l}\text { Negative } \\
\text { distance }\end{array}$ & $\begin{array}{l}\text { Positive } \\
\text { distance }\end{array}$ \\
\hline $\begin{array}{l}\text { Macro- } \\
\text { regional }\end{array}$ & $\begin{array}{l}(-0.5)= \\
\text { EM- } \\
\text { PLOYTER } \\
T \quad(-)\end{array}$ & $\begin{array}{l}0.5=(\text { UR); } \\
1=\text { EMPLOY- } \\
\text { MANUF } \\
\qquad \underline{(+)}\end{array}$ & $\begin{array}{l}(-1.5)= \\
\text { EM- } \\
\text { PLOYAGR } \\
\text { and UR } \\
\qquad(+)\end{array}$ & $\begin{array}{l}1 \text { - } 1.5= \\
\text { EMPLOY- } \\
\text { TER, EM- } \\
\text { PLOYEES } \\
\text { and EM- } \\
\text { PLOY } \\
\quad \underline{(+)}\end{array}$ & $\begin{array}{l}(-1)-(-1.5)= \\
\text { EMPLOY- } \\
\text { MANUF, } \\
\text { EM- } \\
\text { PLOYTERT, } \\
\text { EMPLOY } \\
\text { and EM- } \\
\text { PLOYEES } \\
\quad(-)\end{array}$ & $\begin{array}{c}\text { 1= EM- } \\
\text { PLOYAGR } \\
\text { and UR } \\
(-)\end{array}$ \\
\hline $\begin{array}{l}\text { Character- } \\
\text { istics of } \\
\text { the quality } \\
\text { of employ- } \\
\text { ment (\% of } \\
\text { total statis- } \\
\text { tical units) }\end{array}$ & $\begin{array}{l}\text { close to the } \\
\text { national } \\
\text { average }\end{array}$ & $50 \%$ & good & $25 \%$ & weak & $25 \%$ \\
\hline
\end{tabular}


Exploring the Quality of Employment in Romania at Different Territorial Levels

Synthetic outline of different territorial levels in terms of quality of employment

Table 1

\begin{tabular}{|c|c|c|c|c|c|c|}
\hline Territorial & Class 1 & & Class 2 & & Class 3 & \\
\hline & $\begin{array}{l}\text { Negative } \\
\text { distance }\end{array}$ & $\begin{array}{l}\text { Positive } \\
\text { distance }\end{array}$ & $\begin{array}{l}\text { Negative } \\
\text { distance }\end{array}$ & $\begin{array}{l}\text { Positive } \\
\text { distance }\end{array}$ & $\begin{array}{l}\text { Negative } \\
\text { distance }\end{array}$ & $\begin{array}{l}\text { Positive } \\
\text { distance }\end{array}$ \\
\hline Regional & $\begin{array}{l}(-1)=\text { EM- } \\
\text { PLOYMANU } \\
\text { F, EM- } \\
\text { PLOYTERT, } \\
\text { EMPLOY- } \\
\text { EES and } \\
\text { EMPLOY } \\
\quad(-)\end{array}$ & $\begin{array}{c}\text { 1= EM- } \\
\text { PLOYAGR } \\
\text { and UR } \\
(-)\end{array}$ & $\begin{array}{l}(-2)=\text { EM- } \\
\text { PLOYAGR } \\
\text { and UR } \\
\qquad(+)\end{array}$ & $\begin{array}{l}\text { 2= EM- } \\
\text { PLOYMANU } \\
\text { F, EM- } \\
\text { PLOYTERT, } \\
\text { EMPLOY- } \\
\text { EES and } \\
\text { EMPLOY } \\
\quad(\mathbf{+})\end{array}$ & $(=)$ & $\begin{array}{l}\text { 1= EM- } \\
\text { PLOYMA } \\
\text { NUF } \\
\underline{(+)}\end{array}$ \\
\hline $\begin{array}{l}\text { Character- } \\
\text { istics of the } \\
\text { quality of } \\
\text { employ- } \\
\text { ment (\% of } \\
\text { total statis- } \\
\text { tical units) }\end{array}$ & weak & $50 \%$ & good & $12.5 \%$ & $\begin{array}{l}\text { close to the } \\
\text { national } \\
\text { average }\end{array}$ & $37.5 \%$ \\
\hline County & (E) & $\begin{array}{l}0.5=\text { EM- } \\
\text { PLOYMAN } \\
\text { UF } \\
\quad \underline{(+)}\end{array}$ & $\begin{array}{l}(-1.5)= \\
\text { EM- } \\
\text { PLOYAGR } \\
\text { and UR } \\
\qquad(+)\end{array}$ & $\begin{array}{l}\text { 0.5= EM- } \\
\text { PLOYMANU } \\
\text { F } \\
1=\text { EM- } \\
\text { PLOY, EM- } \\
\text { PLOYTERT } \\
\text { and EM- } \\
\text { PLOYEES } \\
(\mathbf{+})\end{array}$ & $\begin{array}{l}(-0.5)=\text { EM- } \\
\text { PLOY } \\
(-1)=\text { EM- } \\
\text { PLOYMANU } \\
\text { F, EM- } \\
\text { PLOYTERT } \\
\text { and EM- } \\
\text { PLOYEES } \\
(-)\end{array}$ & $\begin{array}{c}0.5=\text { UR } \\
1=\text { EM- } \\
\text { PLOYAGR } \\
(-)\end{array}$ \\
\hline $\begin{array}{l}\text { Character- } \\
\text { istics of the } \\
\text { quality of } \\
\text { employ- } \\
\text { ment (\% of } \\
\text { total territo- } \\
\text { rial admin- } \\
\text { istra- } \\
\text { tive units) }\end{array}$ & $\begin{array}{l}\text { close to the } \\
\text { national } \\
\text { average }\end{array}$ & $47.6 \%$ & good & $21.4 \%$ & weak & $30.9 \%$ \\
\hline
\end{tabular}


Irena MOCANU, Paul-Răzvan ȘERBAN

Synthetic outline of different territorial levels in terms of quality of employment

Table 1

\begin{tabular}{|c|c|c|c|c|c|c|}
\hline Territorial & Class 1 & & Class 2 & & Class 3 & \\
\hline & $\begin{array}{l}\text { Negative dis- } \\
\text { tance }\end{array}$ & $\begin{array}{l}\text { Positive } \\
\text { distance }\end{array}$ & $\begin{array}{l}\text { Negative } \\
\text { distance }\end{array}$ & $\begin{array}{l}\text { Positive } \\
\text { distance }\end{array}$ & $\begin{array}{l}\text { Negative } \\
\text { distance }\end{array}$ & Positive distance \\
\hline LAU2 & $\begin{array}{l}(-0.5)=\text { EM- } \\
\text { PLOYEES } \\
(-1)=\text { EMPLOY- } \\
\text { MANUF and } \\
\text { EMPLOYTERT } \\
\underline{(-)}\end{array}$ & $\begin{array}{c}1=\text { EM- } \\
\text { PLOYAGR } \\
(-)\end{array}$ & $\begin{array}{c}(-1)= \\
\text { EMPLOY } \\
(-)\end{array}$ & $\begin{array}{c}0.5=\text { UR } \\
(-)\end{array}$ & $\begin{array}{l}(-1)= \\
\text { EMPLOY } \\
\frac{(-)}{(-2.5)=} \\
\text { EM- } \\
\text { PLOYAG } \\
\text { R }\end{array}$ & $\begin{array}{l}2.5=\text { EMPLOY- } \\
\text { EES, EMPLOY- } \\
\text { MANUF, and } \\
\text { EMPLOYTERT } \\
1=\text { UR } \stackrel{(+)}{(-)}\end{array}$ \\
\hline $\begin{array}{l}\text { Characteris- } \\
\text { tics of the } \\
\text { quality of } \\
\text { employment } \\
\text { (\% of total } \\
\text { territorial } \\
\text { administra- } \\
\text { tive units) }\end{array}$ & weak & $44.7 \%$ & $\begin{array}{l}\text { close to } \\
\text { the na- } \\
\text { tional } \\
\text { average }\end{array}$ & $48.4 \%$ & $\begin{array}{l}\text { relatively } \\
\text { good }\end{array}$ & $6.8 \%$ \\
\hline
\end{tabular}

(Source: authors' compilation)

$\underline{(+)}=$ positive effect on the quality of employment; $(-)=$ negative effect on the quality of employment; $(\underline{E})=$ neutral effect on the quality of employment.

Positive distances: weak $=0.5$, notable $=0.5-1.0$, sharp $=1.0-1.5$, strong $=>1.5$;

Negative distances: weak $=(-0.5)$, notable $=(-0.5)-(-1.0)$, sharp $=(-1.0)-(-1.5)$, strong $=<(-1.5)$.

EMPLOY = general rate of employment; UR = rate of unemployment; EMPLOYAGR = rate of employment in agriculture; EMPLOYMANUF = manufacturing sector; EMPLOYTERT = rate of employment in the tertiary sector; EMPLOYEES $=\%$ of employees per total employed population.

The good quality of employment is characteristic for the Macro-region III, the Development Region Centre and for the western and central counties, for two southern and south-eastern counties and for the Bucharest Municipality.

Also, a relatively good quality of employment was recorded for the large and medium Danubian municipalities and towns; - generally, the quality of employment at local level appears to be weak (class 1 in types of LAU2), even in the situation in which the quality of employment is close to the baseline existing deviations with negative effects (e.g. the general occupancy below de national average, the unemployment rate above the baseline). This weak quality of employment at local level is matched with the weak quality employment recorded by the Danubian counties (class 3 in types of counties) and even with the weak quality of employment registered by the Development Region South-West (class 1 in the types of regions) (Table 1).

This type of research has some practical implications, enabling decision-makers to act by taking into account the relationships established between the different structures of employment (occupancy in agricultural and in non-agricultural activities, the employees, the employed and the unemployed population). 


\section{Acknowledgments}

This paper was supported by the Priority Research Project of the Romanian Academy, "The Geographic Study of the Romanian Danube Valley", conducted under the Institute of Geography's research plan.

\section{References}

ACELEANU M. I. (2012), Links between education, employment and quality of life. The case of Romania, Management \& Marketing Challenges for the Knowledge Society 7 (4), 717-730.

AKYEAMPONG E. B. (1996), Another measure of employment. Perspectives, Statistics. Wileter, Othawa.

ANDREN D., MARTINSSON P. (2006), What Contributes to Life Satisfaction in Transitional Romania? Review of Development Economics 10 (1), 59-70.

ANKER R., CHERNYSHEV I., EGGER P., MEHRAN F., RITTER J. A. (2003), Measuring Decent Work with Statistical Indicators, International Labour Review 142 (2), 147-178.

ARVIGAN T., BIVENS L. J., GAMMAGE S. (eds.) (2005), Good Jobs, Bad Jobs, No Jobs: Labor Markets and Informal Work in Egypt, El Salvador, India, Russia, and South Africa, Economic Policy Institute, Washington, D.C.

BALKYTE A., TVARONAVIČIENE M. (2010), Perception of competitiveness in the context of sustainable development: Facets of "sustainable competitiveness", Journal of Business Economics and Management 11 (2), 341-365.

van BASTELAER A., HUSSMANNS R. (2000), Measurement of the Quality of Employment: Introduction and overview, Joint ECE-Eurostat-ILO Seminar, Geneva.

van BASTELAER A. (2002), Work organisation, a dimension of job quality: Data from the ad hoc module of the 2001 labour force survey in the EU, Joint UNECE-Eurostat-ILO Seminar, Geneva.

BESCOND D., CHÂTAIGNIER A., MEHRAN F. (2003), Seven indicators to measure decent work: An international comparison, International Labour Review 142 (2), 179-212.

BONNET F., FIGUEIREDO J. B., STANDING G. (2003), A family of decent work indexes, International Labour Review 142 (2), 213-238.

BUDZIANOWSKI W. M. (2012), Target for national carbon intensity of energy by 2050: A case study of Poland's energy system, Energy 46 (1), 575-581.

BURCHELL B., SEHNBRUCH K., PIASNA A., AGLONI N. (2012), The Quality of Employment in the Academic Literature: Definitions, Methodologies, and Ongoing Debates, Working Papers 1, Retrieved from: www.dev-out.cl.

CAPROS P., PAROUSSOS L., FRAGKOS P., TSANI S., BOITIER B., WAGNER F.,

BUSCH S., RESCH G., BLESL M., BOLLEN J. (2014), European decarbonisation pathways under alternative technological and policy choices: $A$ multi-model analysis, Energy Strategy Reviews 2 (3-4), 231-245.

CASTREE N., COE N., WARD K., SAMERS M. (2004), Spaces of Work: Global Capitalism and Geographies of Labour, Sage, London.

CASTREE N. (2010), Workers, economies, geographies, in: MCGRATH-CHAMP S., HEROD A., RAINNIE A. (eds.), Handbook of Employment and Society: Working Space, Edward Elgar Publishing, Cheltenham, pp. 457-476.

CLARK D. A. (2000), Capability and Human Development, An Essay in Honour of Amartya K. Sen, Working Paper 39, University of Lincolnshire and Humberside, Lincoln.

COOKE P., DE PROPRIS L. (2011), A policy agenda for EU smart growth: the role of creative and cultural industries, Policy Studies 32 (4), 365-375.

CIUTACU C., CHIVU L. (2007), Calitatea muncii şi a ocupării forţei de muncă în România, Eurofound, Retrieved from: www.eurofound.europa.eu. 
DAVOINE L., ERHEL C., GUERGOAT-LARIVIERE M. (2008), Monitoring quality in work: European Employment Strategy indicators and beyond, International Labour Review 147 (2-3), 163-198.

EUROFOUND (2013), Eurofound yearbook 2012: Living and working in Europe, Publications Office of the European Union, Luxembourg.

EUROPEAN COMMISSION (2010), EUROPE 2020: A European strategy for smart, sustainable and inclusive growth, Brussels, Retrieved from: www.ec.europa.eu.

EUROPEAN COMMISSION (2015), Country Report: Romania 2015. Including an In-Depth Review on the prevention and correction of macroeconomic imbalances, Brussels, Retrieved from: www.ec.europa.eu. $542-562$

FERRANTE F. (2009), Education, Aspirations and Life Satisfaction, Kyklos 62 (4),

GALLIE D. (2007), Production Regimes and the Quality of Employment in Europe, Annual Review of Sociology 33, 85-104.

GHAI D. (2003), Decent work: Concept and indicators, International Labour Review 142 (2), 113-145. 71-78.

GOSCHIN Z. (2008), Regional Disparities in Romania, Romanian Statistical Review 1,

GREENHAUS J. H., COLLINS K. M., SHAW J. D. (2003), The relation between workfamily balance and quality of life, Journal of Vocational Behavior 63 (3), 510-531.

7 (2), 97-109.

HEROD A. (1997), From a geography of labor to a labor geography: labor's spatial fix and the geography of capitalism, Antipode 29 (1), 1-31.

IANOŞ I. (1999), Restructurarea economică şi fenomenul de migraţie în România, Revista Geografică $5,8-13$.

ILO (1999), Decent Work: Report of the Director General, International Labour Office,

Retrieved from: www.ilo.org.

JOHRI R. (2005), Work values and the quality of employment: A literature review,

Retrieved from: www.dol.govt.nz.

LAZAROIU G. C., ROSCIA M. (2012), Definition methodology for the smart cities model, Energy 47 (1), 326-332.

LESCHKE J., THEODOROPOULOU S., WATT A. (2012), How do economic governance reforms and austerity measures affect inclusive growth as formulated in the Europe 2020 Strategy? in: LEHNDORFF S. (ed.), A triumph of failed ideas: European models of capitalism in the crisis, European Trade Union Institute, Bruxelles, pp. 243-281.

MARTIN R. L. (2000), Local labour markets: their nature, performance, and regulation,

in: CLARK G. L., FELDMAN M. P., GERTLER M. S. (eds.), The Oxford Handbook of Economic Geography, Oxford University Press, Oxford, pp. 445-476.

MARTIN R., MORISSON P. S. (eds.) (2003), Geographies of labour market inequality, Routledge, London.

MATEOC-SÎRB N., MATEOC T., MĂNESCU C., GRAD I. (2014), Research on the labour force from Romanian agriculture, Scientific Papers Series Management, Economic Engineering in Agriculture and Rural Development, 14 (1), 215-218. MĂRGINEAN I., BĂLAŞA A. (coord.) (2005), Calitatea vieţii în România, Expert, Bucharest.

MĂRGINEAN I., PRECUPETU I. (coord.) (2008), Calitatea vieţii şi dezvoltarea durabilă.

Politici de întărire a coeziunii sociale, Expert, Bucharest. MĂRGINEAN I., PRECUPEŢU I. (coord.) (2011), The Quality of Life Paradigm, Romanian Academy Publishing House, Bucharest.

MOCANU I. (2010), Unemployment in Romania during the current economic-financial crisis. Territorial particularities, Human Geographies 4 (2), 109-113.

MORETTI E. (2004), Estimating the social return to higher education: evidence from longitudinal and repeated cross-sectional data, Journal of Econometrics 121 (1-2), 175-212. 
MUÑOZ DE BUSTILLO R., FERNÁNDEZ-MACÍAS E., ANTÓN J. I., ESTEVE F. (2009), Indicators for Job Quality in the European Union, European Parliament, Brussels. New York.

PECK J. (1996), Work-Place: The Social Regulation of Labor Markets, Guilford Press,

PECK J. (2003), Places of work, in: Sheppard E., Barnes T. J. (eds.), A Companion to Economic Geography, Blackwell Publishing Ltd., Oxford, pp. 133-148.

ROKACH L., MAIMON O. (2010), Clustering Methods, in: MAIMON O., ROKACH L.

(eds.), Data Mining and Knowledge Discovery Handbook, Springer, New York, pp. 321-352.

ROCHEFORT R. (1961), Le travail en Sicile, P.U.F., Paris.

SEHNBRUCH K. (2004), From the quantity to the quality of employment: An application of the Capability Approach to the Chilean labor market, Working Papers, Retrieved from: www.clas.berkeley.edu.

SEN A. (1997), Inequality, unemployment and contemporary Europe, International Labour Review 136 (2), 155-171.

ŞERBAN P.-R., TĂLÂNGĂ C. (2015), Is social resilience an economic structure issue or just the ability of communities to cope with external stress? Journal of Urban and Regional Analysis 7 (1), 59-68.

VASILE M., TUFĂ L., PREOTEASA A. M., PRECUPEȚU I., POPESCU R., NEAGU G., MIHALACHE F. F., MIHĂILESCU A., MĂRGINEAN I., DUMITRU M. (2011), Calitatea vieţii în România 2010, Inova lia Socială 3 (1), 1-77.

WELLER S. A. (2008), Are labour markets necessarily 'local'? Spatiality, segmentation and scale, Urban Studies 45 (11), 2203-2223.

WELLER S. A., Campbell I. (2014), The Geography of Job Quality, in: Warhurst J., Knox A., Job Quality in Australia, Federation Press, Sydney, 18 pp.

ZAMFIR C. (1990), Calitatea vieţii ca obiectiv politic, Calitatea vieţii 1, 5-20.

Initial submission: 19.09.2015

Revised submission: 11.11.2015

Final acceptance: 04.12.2015

Correspondence: Institute of Geography, Romanian Academy, 12 Dimitrie Racovita Street, 023993, Sector 2, Bucharest, Romania

E-mail: mocanitai@yahoo.com 
